\title{
Where Are the Poor Located? A Spatial Heterogeneity Analysis of Monetary Poverty in Peru
}

\author{
Juan Palomino ${ }^{a, »}$, Thyara Sánchez ${ }^{\mathrm{b}}$ \\ a Department of Economics, PUCP, Lima, Peru \\ (D) 0000-0003-2828-8424 $\bowtie$ juan.palominoh@pucp.pe " Corresponding author \\ ${ }^{\mathrm{b}}$ Department of Economics, PUCP, Lima, Peru \\ (D) 0000-0002-8902-9285 $\bowtie$ thyara.sanchez@pucp.pe
}

\begin{abstract}
Measuring poverty is a first step to the design of effective public policies, however, it is also essential to know where the poor are located. The main objective of this research is to evaluate the spatial heterogeneity of the factors that influence monetary poverty for each district in Peru. We apply a Geographically Weighted Regression (GWR) approach, which allows us to capture the non-stationarity of the hidden data and to provide coefficients for each district, unlike the OLS model. This research mainly uses the Poverty Map and the Population and Household Census of Peru, both from 2007 and 2017. The overriding findings of our results indicate that female headship, secondary education, electricity, and sanitation services are directly associated with poverty reduction at the local level. For 2007, significant effects are mainly concentrated in the districts of Pasco, Lima and Cajamarca regions. For 2017, the results show a shift towards districts of Junín, Huancavelica, and Cajamarca regions. Likewise, it is highlighted that the highest mean negative effect on poverty is generated by Secondary Education in the GWR estimates; while malnutrition represents the highest mean positive effect on poverty for the level and intercensal models. Finally, the empirical evidence found in this research can help establish better policy designs at the district level.
\end{abstract}

Article History: Received: August 012020 / Revised: September 282020 / Accepted: March 162021 Keywords: Geographically Weighted Regression; Monetary poverty; Poverty mapping; Spatial heterogeneity; Spatial nonstationary; Peru

JEL Classification: C14, C21, I32, P25, R12 


\section{Introduction}

Most researchers have carried out systematic and detailed studies about poverty measurements, the evolution of poverty dynamics, the mechanisms that cause poverty and strategies to reduce poverty (Escobal et al., 1999; Herrera and Cozzubo, 2016; Verdera, 2007). Nevertheless, little attention has been paid to the socioeconomic accessibility factors that explain the spatial heterogeneity of poverty in Peru at different territorial levels ( $\mathrm{Li}$ et al., 2020). In this case, the spatial heterogeneity refers to the fact that the poor population is located and assembled in specific geographical areas. Therefore, determining the spatial heterogeneity of poverty is one of the issues that has generated most concern in the field of public policies in different countries.

For that reason, one of the tools that makes possible to spatially represent diverse economic, social and environmental characteristics of a country at any administrative territorial level is the Poverty Map. It gives out information to capture the existent heterogeneity of poverty and identify clusters to design social policies and prioritize the scope of intervention at the local level. In Peru, the National Institute of Statistics and Informatics (known as INEI by its initials in Spanish) elaborates the poverty map based on a monetary approach. It should be noted that monetary poverty indicator is the official measure in Peru and the main indicator of this study, despite its limitations with respect to other approaches such as multidimensional poverty (Clausen and Flor, 2014). The monetary poor population is defined by INEI as those who reside in households whose per capita outlay is not enough to acquire a basic food basket and non-food items (housing, clothing, education, health, transportation, etc.).

According to INEI estimates, Peru has achieved considerable success in reducing monetary poverty over the last 15 years, denominating this period as pro-poor because poor population has decreased from $58.7 \%$ for 2004 to $20.2 \%$ for 2019 , in a context of high economic growth for the country (Cord et al., 2015; Aldana et al., 2019). Though this systematic decrease in national poverty, high rates of poverty in rural areas still persist, with a value of $40.8 \%$ in 2019 , 20 percentage points higher than the national level, representing an outstanding challenge for public policies designed to rural context. To highlight this point, the increasing complexity of the poverty problem emphasizes the importance of conducting poverty research at a local level to achieve targeted policy implementation and enhance the effects of poverty reduction (Li et al., 2020).

The measurement of poverty is a fundamental first stage to the design of effective social policies. However, a second stage is to identify where the poor are really located in the Peruvian territory. Thus, the main objective of this research is twofold. First, we evaluate the main factors that influence over the spatial heterogeneity of monetary poverty using a Geographically Weighted Regression (GWR) model. Second, we try to contribute to the literature by providing territorial policy recommendations to address poverty in the different districts. To our knowledge this is the first time that spatial heterogeneity of monetary poverty has been evaluated for Peru. Moreover, the main advantages of this econometric approach is to capture the spatial variability of the data and to provide estimates for each territorial administrative level, in contrast to an OLS model, whose factors are constant in all districts. We use data from the 2007 and 2017 Poverty Maps and Population and Household Census of Peru to estimate two level models corresponding 
to both years and an inter-census model, considering variables related to education, work, health, among others.

The results of this research allow us to identify the districts with significant local coefficients of the different socioeconomic variables on poverty. On the one hand, the increase in secondary education, electricity, sanitation services or female headship has an effect on poverty reduction, predominantly in districts of the regions of Pasco (central highlands), Lima (central coast) and Cajamarca (north) for 2007; while for 2017, this significant effect is registered in the regions of Junín, Huancavelica and Cajamarca. On the other hand, unemployment, malnutrition and altitude are factors that contribute to the increase in poverty in districts of the regions of Ancash (central coast), Arequipa and Ayacucho (south) for 2007; while for 2017, this effect is concentrated in the districts of the Cusco, Tacna and Áncash regions. In addition to these main findings, it is highlighted that the largest average negative effect on poverty is generated by secondary education in the GWR estimates; while malnutrition represents the largest average positive effect on poverty for both the level and intercensal models.

The document is structured as follows. Section 2 presents a brief empirical review. Section 3 explains the methodology of geographically weighted regressions. Section 4 shows the databases and describes statistics of the variables used for the study. Section 5 presents the results of the spatial patterns of poverty, as well as the estimates of the GWR model. Finally, Section 6 presents the conclusions and policy recommendations.

\section{Literature Review}

In most countries, poverty is closely related to the geographical environment (Jalan and Ravallion, 2002; Kraay and McKenzie, 2014). Researchers such as Xu et al. (2019); Qu et al. (2012); Olivia et al. (2011) confirm the hypothesis that the characteristics of the local natural environment, specifically geographic conditions, are strongly related to regional poverty. Additionally, Bird et al. (2011) mention that physical isolation contributes to the emergence of a spatial poverty trap; that physical isolation contributes to the emergence of a spatial poverty trap, usually found in remote geographic areas; fragile ecological environments; poor public infrastructure and politically disadvantaged areas.

In this section, the main factors that explain territorial poverty in the Peruvian context are reviewed. A first variable that has an effect on poverty is related to access to services. For example, having access to basic services such as electricity, sanitation, and drinking water is relevant to reduce the vulnerability of households in the economy. Reinikka and Svensson (1999) mention that housing infrastructure is the capital that provides the necessary support services to undertake private activities. Thus, a household that does not have access to drinking water, sewerage or electricity has no possibility of obtaining a better wellbeing and, therefore, its economic position is seriously affected. Among the studies that have analyzed access to basic services as a determinant of poverty in the Peruvian case, Escobal et al. (1999) found significant impacts of the drinking water, sewage, electricity, and telephone service on poverty, highlighting that the lack of access to certain assets generates insufficient income flows to fight poverty. Moreover, Aparicio et al. (2011) have conducted a study where they conclude that 
the probability of being poor fluctuates from $12 \%$, when the household has water, sewerage, electricity and telephone access, to $45 \%$ when it does not have any of these four services.

Another determinant of poverty is education. Becker (1964) mentioned that investment in human capital is key to economic progress, both at the macro (country, region) and micro (individual) levels. In the Peruvian case, Benavides (2004) mentions that, although there are variable social conditions, education always increases the probability of social mobility and has an intergenerational role, that is, as parents become more educated, the educational level of the children will be higher, and therefore, they will be able to escape from poverty. Ordaz (2009) points out that, in the context of the rural sector in Mexico, a person with completed secondary education reduces, significantly, their probability of being in a situation of poverty, compared to a person with only a complete primary education, concluding that, a higher educational level represents an effective instrument for overcoming poverty.

Another relevant variable affecting poverty is chronic child malnutrition. According to the World-Bank (2006), malnutrition slows economic growth and perpetuates poverty through three pathways: (i) low productivity resulting from poor health status; (ii) impaired cognitive functions and lack of schooling; and (iii) increased health care costs. Likewise, this evidence converges towards the formation of a vicious cycle. For instance, child malnutrition has consequences in adulthood, generating a reduction in human capital and wages, associated with fewer years of education due to lower cognitive development, also generating limitations in productivity. These factors make it difficult to overcome poverty. In turn, these adults conform families whose children are at greater risk of being harmed by child malnutrition (Segura et al., 2002). In the Peruvian case, Alcázar et al. (2013) show that the greatest costs generated by malnutrition come mainly from lost productivity; the authors also point out that malnutrition affects the highland and jungle regions of Peru.

The results of the various studies on poverty and gender analysis in household headship are mixed. On the one hand, we have studies that conclude that female headship in the household exacerbates poverty, due to their disadvantage in economic participation, wage gap, discrimination, domestic work, educational level, among others (Moghadam, 1997; Kabeer, 2003; Mahoozi, 2015; Paes de Barros et al., 2006). In contrast, authors such as Cortés (1997) show that poverty is lower in households headed by women, due to the efficiency of household management. Likewise, in-depth studies on the situation of the children of female-headed households show better levels of nutrition, health and education (Blumberg, 1995; Oppong, 1997). Finally, according to Chant (2003), the debates on female headship of household and poverty have brought into discussion the issue of "empowerment of women", which emphasizes that the ability to control and allocate resources in the household is as important as the power to obtain those resources.

Regarding unemployment, the study by Saunders (2002) finds that the prolongation of unemployment increases the probability of a household falling into poverty. That is, $13 \%$ of poor people in Australia registered being unemployed for eight weeks, while $80 \%$ of the poor registered being unemployed for more than a year. In the Peruvian case, Yamada and Montero (2008) find not only a significant impact of unemployment on the poverty level of the general population, but also which groups are the most vulnerable. Indeed, they find that the incidence of falling

\section{PUCP}


into poverty is higher when household head is unemployed than when a spouse or another member of the household is unemployed. Likewise, they find a higher incidence of poverty when the unemployed household member is a woman.

From this brief literature review, it is inferred that the problem of poverty in Peru not only is related to the social and economic aspects, but also leads to strategies that relate poverty to the geographical location, the environment, and socioeconomic characteristics of a given region. Hence, the increasing complexity of the poverty problem highlights the importance of conducting poverty research at a local level to achieve targeted policy implementation and enhance the effects of poverty reduction ( $\mathrm{Li}$ et al., 2020).

\section{Methodology}

In a spatial analysis context, the link between dependent variable and independent variables varies with changes in geographical location. Such spatial variation is called spatial nonstationarity. However, the linear regression (OLS model) assumes that the effect of explanatory variables remains stable over the region and thus fails to reflect the spatial non-stationarity of different independent variables over the entire area. The equation form of the global regression model (OLS) is as follow:

$$
y_{i}=\beta_{0}+\sum_{k=1}^{m} \beta_{k} x_{i k}+\epsilon_{i}, \quad i=1,2, \ldots, n
$$

where $y_{i}$ is the dependent variable, $x_{i k}$ is the value of the $k$-th independent variable and $\epsilon_{i}$ is the error term. However, we apply the Geographically Weighted Regression (GWR), which allows regression coefficients to vary across space, thereby allowing parameter values to vary between locations (Fotheringham et al., 2003). The authors Brunsdon et al. (1996) introduced the GWR model in the spatial literature by proposing a variation to the linear regression model, which consists of adding information on geographical location to obtain local rather than global parameters. The GWR model is defined as follows:

$$
y_{i}=\beta_{0}\left(\mu_{i}, \nu_{i}\right)+\sum_{k=1}^{m} \beta_{k}\left(\mu_{i}, \nu_{i}\right) x_{i k}+\epsilon_{i}, \quad i=1,2, \ldots, n
$$

where $\left(\mu_{i}, \nu_{i}\right)$ represent the spatial coordinates (latitude, longitude) of the $i-t h$ sample point, and $\beta_{k}\left(\mu_{i}, \nu_{i}\right)$ states the value of the continuous function $\beta_{k}(\mu, \nu)$ of the $i-t h$ location. If $\beta_{k}(\mu, \nu)$ does not vary in space, GWR becomes a global model (OLS). The GWR model is based on the non-parametric locally weighted regression technique where the regression parameters are estimated using data subsets that are close to the model's estimation location in a geographic space (Wheeler and Páez, 2010). These parameters are estimated using a weighting function based on the distance of the geographic coordinates of the data, that is, those variables that are closest to the estimation point will have a greater influence on the estimation. The GWR parameter estimates at location $i$ are solved using the following equation, given in matrix form:

$$
\widehat{\beta}\left(\mu_{i}, \nu_{i}\right)=\left[X^{\prime} W\left(\mu_{i}, \nu_{i}\right) X\right]^{-1} X^{\prime} W\left(\mu_{i}, \nu_{i}\right) Y,
$$


where $\widehat{\beta}_{i}$ is the vector of local regression coefficients at location $i$; $Y$ is the $n \times 1$ vector of dependent variables; $X$ is the matrix of independent variables, which includes a leading column of ones for the intercept; and $W_{i}$ is the $n \times n$ spatial weighting matrix whose diagonal elements denote the geographical weighting for each data at location $i$ (Fotheringham et al., 2001):

$$
W\left(\mu_{i}, \nu_{i}\right)=\left(\begin{array}{ccc}
w\left(d_{i 1}\right) & \ldots & 0 \\
\vdots & \ddots & \vdots \\
0 & \ldots & w\left(d_{i n}\right)
\end{array}\right)_{N \times N}
$$

The spatial weighting matrix, $W\left(\mu_{i}, \nu_{i}\right)$, is calculated using a Kernel function that calculates the weights of the observations inversely related to the distance, that is, it assigns more weight to the data that are closest to the estimation point as opposed to those that are further away. The function commonly used to calculate the spatial weights that monotonically decrease with distance is the Gaussian kernel function (Wheeler and Páez, 2010; Leung et al., 2000):

$$
w_{i j}=\exp \left(-\frac{1}{2}\left(\frac{d_{i j}}{\delta}\right)^{2}\right)
$$

where $d_{i j}$ is the distance between observations $i$ and $j$, and $\delta$ is the kernel bandwidth parameter. The weight $\left(w_{i j}\right)$ for observation $j$ relative to observation $i$ change as a function of the distance $\left(d_{i j}\right)$ and the kernel bandwidth $(\delta)$ controls the range and decay of spatial correlation (Wheeler and Páez, 2010). The weighting through the Kernel function responds to the assumption of spatial autocorrelation that if it is fulfilled, non-stationary patterns will be obtained in the estimated coefficients (Wheeler and Páez, 2010; Páez et al., 2002).

According to the literature, there are two types of Kernels for using in GWR models: adaptive and fixed Kernel functions. We use the adaptive kernel because it adjusts to the density of the data by varying the bandwidth, which is the inverse of density. This allows flexibility to reduce the variance of the estimates in areas with few observations and reducing the bias of the estimates in areas with many observations (Van Kerm, 2003; Bowman and Azzalini, 1997; Pagan and Ullah, 1999). Moreover, adaptive Kernel function estimates are obtained through optimization methods such as Cross Validation (CV), Generalized Cross Validation (GCV), Akaike information criteria (AIC), Akaike information criteria corrected $\left(A I C_{c}\right)$ (Brunsdon et al., 1996; Cleveland, 1979; Van Kerm, 2003; Farber and Páez, 2007; Wheeler and Páez, 2010). We use the procedure $A I C_{c}$ to estimate the bandwith, and its formula is the follow:

$$
A I C_{c}=2 n[\ln (\widehat{\sigma})]+n[\ln (2 \pi)]+n\left[\frac{n+\operatorname{tr}(P)}{n-2-\operatorname{tr}(P)}\right],
$$

where $\widehat{\sigma}$ is the maximum likelihood estimator and $\operatorname{tr}(P)$ is the trace of the projection matrix of the GWR model. It should be noted that the lowest value of $A I C_{c}$ is the best model. Moreover, this criterion allows to compare the degree of adjustment of the GWR estimate with respect to that obtained by OLS.

In addition to the standard GWR model, there is an extension called the Mixed Geographically Weighted Regression (MGWR) model (Mei et al., 2004). It assumes that not all coefficients are variable, that is, there are mixed coefficients in the model: local and global. The model is defined

\section{c) PUCP}


as follow:

$$
y_{i}=\sum_{l=1}^{p} \beta_{l} x_{i l}+\sum_{j=1}^{k} \beta_{j}\left(\mu_{i}, \nu_{i}\right) x_{i j}+\epsilon_{i}, \quad i=1,2, \ldots, n,
$$

where $\beta_{l}(l=1, \ldots, p)$ are fixed or global coefficients, and remaining coefficients vary according to their geographical location, as shown in equation (2). To determine the application between MGWR or GWR, Monte Carlo simulation was used, which sequentially compares the spatial variability of each coefficient. ${ }^{1}$ The advantage of the mixed coefficient model consists in identifying variables that are not affected by the local context and, therefore, detects those factors with a homogeneous impact on the phenomenon to be explained, regardless of their geographical location.

\section{Data and Variables}

This study mainly uses data from the Poverty Map and the Population and Household Census, both for the years 2007 and 2017, made available by INEI. First, the Poverty Map provides information on disaggregated poverty rate at the level of each district in Peru. It is important to mention that this poverty rate is calculated using small area estimates in order to obtain reliable data at district level. ${ }^{2}$ Figure 1 shows the geographical distribution of monetary poverty at district level for both years, 2007 and 2017, and the intercensal change. As can be seen, in 2007, high poverty rates were mainly concentrated in the southern highlands of Peru (Huancavelica, Apurímac and Puno). Unlike 2007, poverty rates in 2017 are concentrated in the northern highlands (Cajamarca and La Libertad) and the jungle (Amazonas and Loreto). As we move towards more densely populated districts on the coast, the numbers decrease, reaching rates of $13 \%$ in 2007 and $1 \%$ in 2017.

Second, the Population and Household Census is designed to capture the socioeconomic development and economic well-being of Peruvian households and individuals, covering multiple dimensions such as educational level, family relationships, housing infrastructure and economic activities. Censuses in Peru are conducted approximately every 10 years. Additionally, an important aspect to mention about both censuses is the difference in the number of districts, that is, the 2007 census has information from 1832 districts, while in the 2017 census this number increases to 1874 districts. Table 1 shows the descriptive statistics of the remaining variables obtained from the census for 2007, 2017 and the intercensal change.

Among the control variables, there are socioeconomical variables such as the percentage of female heads of households, with a rate of $26.5 \%$ in 2007 and $31.3 \%$ in 2017 by district. Another variable is the rate of individuals with completed secondary, whose percentage is $17.1 \%$ in 2007 and 23.3\% in 2017. According to Benavides (2004), a low level of education (primary or secondary) is associated with a high rate of poverty. Hence, there is likely to be an inverse

\footnotetext{
${ }^{1}$ The Monte Carlo test runs once to derive the local parameter estimates and then repeatedly derives new local parameter estimates after randomly rearranging the data points to measure whether the variability of each parameter surface could have arisen by chance. For more details, see Li and Fotheringham (2020).

${ }^{2}$ This data can be dowloaded for 2007 in https://www.inei.gob.pe/media/MenuRecursivo/publicaciones _ digitales/Est/Lib0911/index.htm, and for 2017 in https://www.inei.gob.pe/cifras-de-pobreza/.
} 

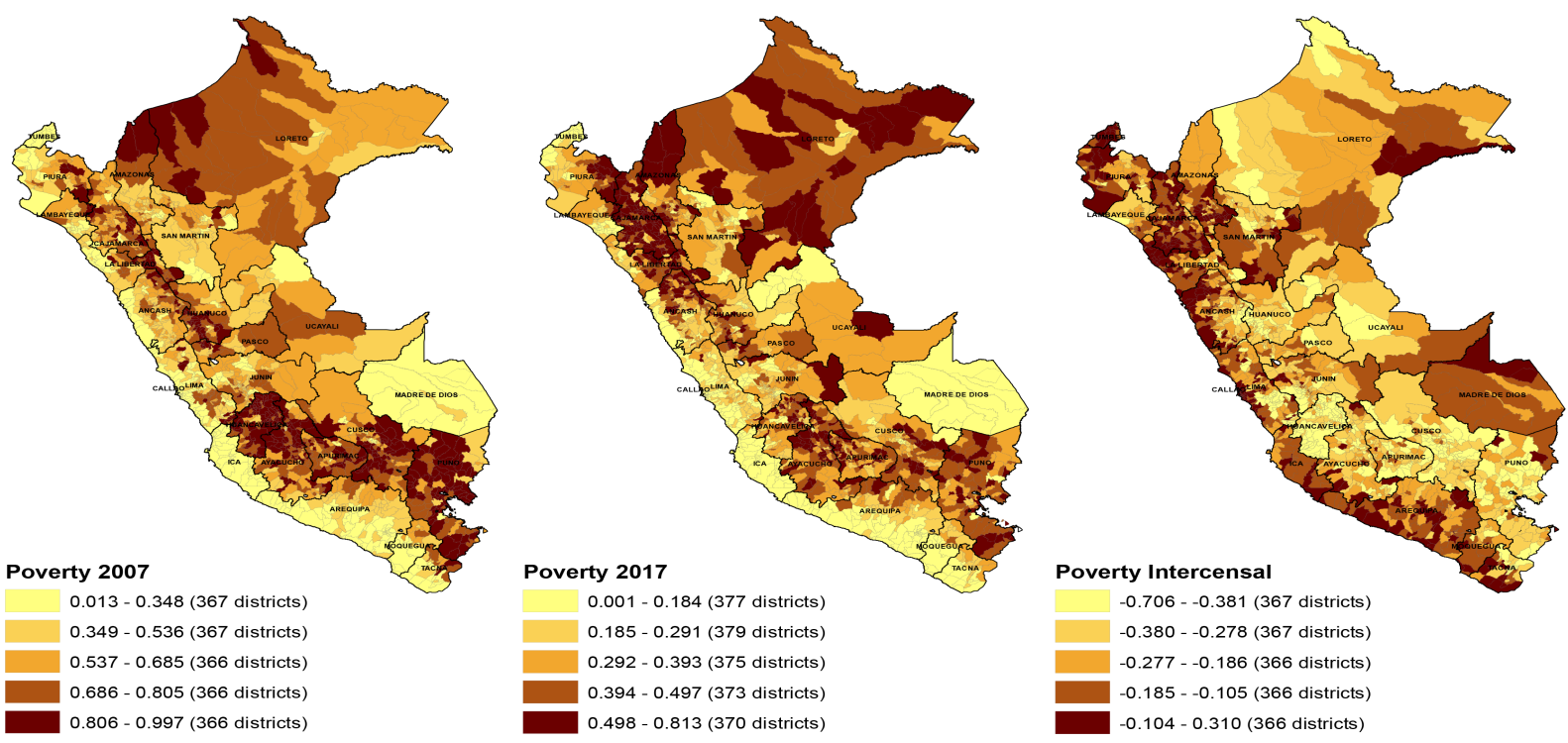

Notes: The territory of Peru is divided into 24 regions. Own elaboration based on INEI.

Figure 1. Spatial distribution of poverty rate.

Table 1

Descriptive statistics of the variables.

\begin{tabular}{|c|c|c|c|c|c|c|c|c|c|c|c|c|}
\hline \multirow[b]{2}{*}{ Variables } & \multicolumn{4}{|c|}{$\begin{array}{c}2007 \\
N=1832 \text { observations }\end{array}$} & \multicolumn{4}{|c|}{$\begin{array}{c}2017 \\
\mathrm{~N}=1874 \text { observations }\end{array}$} & \multicolumn{4}{|c|}{$\begin{array}{c}\text { Intercensal } \\
\mathrm{N}=1832 \text { observations }\end{array}$} \\
\hline & Mean & $\mathrm{SD}$ & Min & $\operatorname{Max}$ & Mean & $\mathrm{SD}$ & Min & $\operatorname{Max}$ & Mean & $\mathrm{SD}$ & Min & $\operatorname{Max}$ \\
\hline Poverty (\%) & 0.581 & 0.229 & 0.013 & 0.997 & 0.341 & 0.169 & 0.001 & 0.81 & -0.241 & 0.152 & -0.706 & 0.310 \\
\hline Female Head (\%) & 0.265 & 0.073 & 0.073 & 0.502 & 0.313 & 0.076 & 0.099 & 0.52 & 0.049 & 0.047 & -0.187 & 0.255 \\
\hline Secondary $\mathrm{E}$ & 0.171 & 0.073 & 0.013 & 0.468 & 0.233 & 0.073 & 0.061 & 0.488 & 0.062 & 0.036 & -0.112 & 0.239 \\
\hline Unemployment (\%) & 0.049 & 0.050 & 0 & 0.433 & 0.037 & 0.035 & 0 & 0.569 & -0.012 & 0.054 & -0.430 & 0.543 \\
\hline Electricity (\%) & 0.405 & 0.207 & 0 & 0.909 & 0.770 & 0.162 & 0 & 1 & 0.367 & 0.171 & -0.506 & 0.907 \\
\hline Sanitation Services (\%) & 0.172 & 0.201 & 0 & 0.905 & 0.417 & 0.269 & 0 & 1 & 0.249 & 0.170 & -0.433 & 0.917 \\
\hline Malnutrition (\%) & 0.385 & 0.179 & 0 & 0.996 & 0.211 & 0.116 & 0 & 0.833 & -0.173 & 0.145 & -0.761 & 0.390 \\
\hline $\operatorname{Ln}$ (Altitude) & 7.095 & 1.609 & 1.099 & 8.476 & 7.139 & 1.493 & 1.609 & 8.456 & 0.049 & 0.242 & -2.019 & 2.965 \\
\hline
\end{tabular}

Note: Own elaboration based on data used in the estimations.

relationship between poverty and the average level education. Similarly, the percentage of unemployment is $4.9 \%$ per district in 2007 , and $3.7 \%$ in 2017 . A positive relationship between the rate of unemployment and poverty is expected (Yamada and Montero, 2008).

There is a group referencing to housing services such as electricity access and sanitation services. In this paper, access to housing services refers to the minimum requirements that housing must meet, such as access to electricity, which represents $40 \%$ on average per district in 2007, while in 2017 the figure rises to $77 \%$. Likewise, sanitation services considers if housing is connected to a public sewage system inside or outside the home, which represents $17.2 \%$ in 2007 , increasing to $41.7 \%$ in 2017 . It should be noted that other variables such as water service or fuel used for cooking were constructed, but they were not considered in the research due to the high correlation with electricity access and sanitation services. 
Likewise, chronic child malnutrition is still a problem that persists in Peru and not only has fatal consequences for those who suffer from it, but for society in general. In the short term, this public health problem causes a high rate of infant mortality (Aparicio et al., 2011). In the medium term, its consequences are seen to the detriment of the physical and cognitive development of minors. The results for chronic child malnutrition in 2007 is $38.5 \%$, while in 2017 is $21.1 \%$.

Further, Peru has a diversity of climates throughout its territory, ranging from the arid and warm coastal areas through the inter-Andean valleys of the temperate, frigid and polar type to those of the warm and rainy type of the jungle. Likewise, it is considered as highly vulnerable to climatic anomalies (MINAM, 2014). According to CAF (2014), Peru is one of the countries in South America that is classified in the "high risk" category of climatic vulnerability, while Paraguay and Bolivia are the only two countries classified as "extreme risk", and Chile is the only country with a "low risk" classification. Thus, the microclimates and the high climatic vulnerability registered in Peru cause that some districts are more affected than others before the variability of the climate. For each year, the altitude of the districts is around $7.1 \%$ m.a.s.l. This variable is used in studies such as Escobal and Ponce (2016) for the case of Peru.

\section{Empirical Results}

This section explains the spatial relationship between the monetary poverty rate and the factors that influence this phenomenon using GWR.

\subsection{Estimations}

The empirical regression analysis begins with the application of a traditional OLS, whose results were standardized in order to compare the degree of impact of each variable on poverty. These results are presented in Table 2 . Almost all variables have statistically significant coefficient and their signs are as expected. Besides, OLS model has high adjusted $R^{2}$ value of $64.3 \%$ and $59.8 \%$ for 2007 and 2017, respectively. However, this value is reduced to $9.4 \%$ for the intercensal model, that is, the explanation for the variability of poverty is very low related to the previous models.

Moreover, Table 2 shows that, in the case of Malnutrition and Altitude, the coefficients are positive and significant at $1 \%$ in all estimates. Particularly, the positive and significant coefficient of Malnutrition obtained from the intercensal model means that the decreasing trend of Malnutrition from 2007 to 2017 is relatively important to explain also the reduction of poverty in that period.

The estimated coefficients for Sanitation Services and Secondary Education are significantly negative at 1\% for the year 2007 and 2017, while for the model in differences, the coefficient has the same sign, but at a significant level at 5\%. About this, although both variables have a lower level of significance in intercensal model, it is recognized that the increase of more people with secondary education and more households with sanitation services between 2007 and 2017 are important to explain the reduction in poverty. In the case of Unemployment, the 
Table 2

Results of linear regression (OLS).

\begin{tabular}{lccc}
\hline Dependent Variable: Poverty rate & 2007 & 2017 & Intercensal \\
\hline Female Head (\%) & $0.035^{* *}$ & $-0.143^{* * *}$ & $0.043^{*}$ \\
& $(0.054)$ & $(0.044)$ & $(0.076)$ \\
Secondary Education (\%) & $-0.175^{* * *}$ & $-0.290^{* * *}$ & $-0.064^{* *}$ \\
& $(0.061)$ & $(0.047)$ & $(0.106)$ \\
Unemployment (\%) & $0.100^{* * *}$ & $0.097^{* * *}$ & 0.032 \\
& $(0.065)$ & $(0.108)$ & $(0.066)$ \\
Electricity (\%) & $-0.122^{* * *}$ & $-0.045^{* *}$ & 0.022 \\
& $(0.025)$ & $(0.023)$ & $(0.022)$ \\
Sanitation services (\%) & $-0.220^{* * *}$ & $-0.273^{* * *}$ & $-0.053^{* *}$ \\
& $(0.024)$ & $(0.013)$ & $(0.021)$ \\
Malnutrition (\%) & $0.332^{* * *}$ & $0.219^{* * *}$ & $0.244^{* * *}$ \\
& $(0.029)$ & $(0.034)$ & $(0.025)$ \\
Ln(Altitude) & $0.178^{* * *}$ & $0.242^{* * *}$ & $0.117^{* * *}$ \\
& $(0.003)$ & $(0.002)$ & $(0.013)$ \\
Adjusted $R^{2}$ & 64.3 & 59.8 & 9.4 \\
AIC & -2079.126 & -3042.335 & -1874.879 \\
$\mathrm{z}$ (Moran I residuals) & $31.116^{* * *}$ & $32.513^{* * *}$ & $33.805^{* * *}$ \\
\hline
\end{tabular}

Note: ${ }^{*},{ }^{* *},{ }^{* *}$ denote statistical significance at $10 \%, 5 \%$ and $1 \%$, respectively. Robust standard errors in parentheses.

coefficients obtained are positive and significant at $1 \%$ on the poverty rate only for 2007 and 2017 estimates. Similar results are observed for Electricity, the coefficient in the intercensal model is not significant, while for 2007 and 2017, the coefficients are significant at 1\% and 5\%, respectively. Finally, in 2007, Female Head shows a positive and significant coefficient at 5\%, whose magnitude is close to the value obtained in the intercensal model, whose significance level is $10 \%$. In contrast to these results, in 2017 , the coefficient is negative and significant at $1 \%$, with a magnitude that quadruples the 2007 value.

In addition, to test the global spatial dependence in the OLS residual, we use Moran I test Moran (1950). This statistic captures the degree to which variables in one location are similar to those in neighboring locations. Using a contiguity matrix, Table 2 presents significant $z$ (Moran I residuals) values of spatial autocorrelation, which gives us the first clue of spatial dependence. However, Moran's I only detects global variation, therefore we explore local variation using the GWR model.

As stated above, GWR has the power to capture and examine the non-stationarity of hidden data by global model (OLS). This non-parametric technique allows obtaining coefficients that vary across the space, thus permitting a different set of coefficients to be obtained for each of the points that form the data. In addition, to obtain these results, a Monte Carlo was first tested to identify whether to use a MGWR or GWR model. The aim is to detect the presence of fixed variables in a mixed model, which can have a uniform impact on poverty, regardless of geographic location. However, as a result, all variables showed significant spatial variability implying local effects on poverty. The results of the GWR model are presented in Table 3, where six statistical values are shown for each variable: mean, minimum, first quartile, median, third quartile and maximum for 2007, 2017 and intercensal. 
Table 3

Results of GWR models.

(a) Census 2007 .

\begin{tabular}{|c|c|c|c|c|c|c|}
\hline Independent Variables & Mean & Minimum & $\begin{array}{c}\text { First } \\
\text { Quartile }\end{array}$ & Median & $\begin{array}{c}\text { Third } \\
\text { Quartile }\end{array}$ & Maximum \\
\hline Female Head (\%) & -0.029 & -1.279 & -0.270 & -0.066 & 0.189 & 1.182 \\
\hline Secondary Education (\%) & -0.589 & -2.305 & -0.960 & -0.523 & -0.158 & 1.427 \\
\hline Unemployment (\%) & 0.098 & -3.944 & -0.113 & 0.117 & 0.336 & 2.782 \\
\hline Electricity (\%) & -0.084 & -0.530 & -0.190 & -0.077 & 0.024 & 0.564 \\
\hline Sanitation services (\%) & -0.230 & -0.752 & -0.386 & -0.216 & -0.081 & 0.491 \\
\hline Malnutrition (\%) & 0.343 & -0.480 & 0.089 & 0.303 & 0.494 & 1.550 \\
\hline $\operatorname{Ln}($ Altitude $)$ & 0.097 & -0.642 & 0.014 & 0.053 & 0.146 & 0.880 \\
\hline Goodness of fit & \multicolumn{2}{|c|}{ Adjusted $R^{2}$ : 83.9} & & & \multicolumn{2}{|c|}{ AICc: -3181.9 } \\
\hline
\end{tabular}

(b) Census 2017.

\begin{tabular}{|c|c|c|c|c|c|c|}
\hline Independent Variables & Mean & Minimum & $\begin{array}{c}\text { Fisrt } \\
\text { Quartile }\end{array}$ & Median & $\begin{array}{c}\text { Third } \\
\text { Quartile }\end{array}$ & Maximum \\
\hline Female Head (\%) & -0.317 & -1.189 & -0.460 & -0.313 & -0.153 & 0.509 \\
\hline Secondary Education (\%) & -0.359 & -1.885 & -0.589 & -0.394 & -0.140 & 0.632 \\
\hline Unemployment (\%) & 0.318 & -2.213 & 0.030 & 0.242 & 0.607 & 3.719 \\
\hline Electricity (\%) & -0.092 & -0.433 & -0.172 & -0.088 & -0.020 & 0.338 \\
\hline Sanitation services (\%) & -0.156 & -0.470 & -0.217 & -0.138 & -0.089 & 0.087 \\
\hline Malnutrition (\%) & 0.295 & -0.192 & 0.158 & 0.289 & 0.427 & 0.995 \\
\hline $\operatorname{Ln}($ Altitude $)$ & 0.045 & -0.448 & 0.012 & 0.041 & 0.082 & 0.317 \\
\hline Goodness of fit & \multicolumn{3}{|c|}{ Adjusted $R^{2}: \mathbf{8 0 . 7}$} & & \multicolumn{2}{|c|}{ AICc: -4171.3} \\
\hline
\end{tabular}

(c) Intercensal.

\begin{tabular}{lccccc}
\hline Independent Variables & Mean & Minimum & $\begin{array}{c}\text { First } \\
\text { Quartile }\end{array}$ & Median & $\begin{array}{c}\text { Third } \\
\text { Quartile }\end{array}$ \\
\hline Female Head (\%) & 0.098 & -0.924 & -0.130 & 0.072 & 0.293 \\
Secondary Education (\%) & -0.117 & -2.477 & -0.368 & 0.035 & 0.304 \\
Unemployment (\%) & 0.046 & -1.431 & -0.132 & 0.116 & 0.314 \\
Electricity (\%) & -0.076 & -0.521 & -0.134 & -0.066 & 0.008 \\
Sanitation services (\%) & -0.014 & -0.327 & -0.095 & -0.009 & 0.060 \\
Malnutrition (\%) & 0.122 & -0.496 & 0.032 & 0.152 & 0.274 \\
Ln(Altitude) & 0.108 & -2.115 & -0.033 & 0.047 & 0.310 \\
Goodness of fit & Adjusted $R^{2} \mathbf{5 0 . 7}$ & & 0.185 & 0.3267 \\
\hline
\end{tabular}

Note: Own elaboration based on data used in the estimations.

On the one hand, it is highlighted that the highest negative mean effect on poverty is generated by Secondary Education for 2007, 2017 and intercensal, with mean values of $-0.589,-0.359$ and -0.117 , respectively, the sign being stable with that obtained in the OLS. These results may be related to the fact that in recent years there have been positive changes in the completion of secondary education, particularly in historically disadvantaged areas. Likewise, the route for decentralized management established since 2002 is probably driving the favorable effect against poverty by adapting the educational offer to the heterogeneity of the national territory (Reátegui et al., 2017).

On the other hand, Malnutrition represents the largest mean positive effect on poverty for the model in levels and intercensal with mean values of $0.343,0.295$ and 0.122 , respectively, coinciding with the sign obtained in the OLS. In effect, Peru has made great progress in reducing 
malnutrition not only in rural areas but also in urban areas in all regions. This improvement is possibly due to the high economic growth rates registered for more than a decade which, in addition to increasing household income, allowed the government to increase spending on social programs such as the Juntos program. According to Sanchez et al. (2016), exposure to the Juntos program during the first three years of life reduces by 13.4 percentage points the probability of suffering from severe stunting, decreasing the risks of deterioration of cognitive functions, low productivity and poverty.

In the case of Unemployment, the mean value in 2007 is 0.098 , close to that obtained in the OLS; however, this mean value is reduced to almost half, 0.046, for the intercensal estimation. For both models, the local coefficients fluctuate between negative and positive values, but the latter predominating. A similar behavior is observed in 2017, whose mean value increases to 0.318 , however the central local coefficients are concentrated in positive values fluctuating between 0.030 and 0.607. In relation to this, Franco and Nopo (2018) report an important finding, in the period from 2006 and 2016, the authors evidenced that the proportion of poor young people who are part of the Employee Assistance Program (EAP) in Peru decreased by 10 percentage points. That is, young people are giving up the labor market, probably after failing to find any job or quality employment. This becomes a cause for concern, as according to the asset approach of the poor, part of the population in poverty can escape from poverty as long as their asset holdings vary, therefore, employment can be a source of income that would explain the exit from poverty or return to it, otherwise, according to Escobal et al. (1999).

In relation to the variables about household condition, the average values of the local coefficients of Electricity and Sanitation are negative for the three estimated models, and the values of the 25 th and 75 th percentiles are predominantly negative for these two variables, which means that this inverse effect on poverty occurs in most districts of Peru. These results are in accordance with that presented by Aparicio et al. (2011), who affirm that having access to electricity and sanitation is of the most importance to reduce the vulnerability of households. Moreover, Fukusaki and Pérez (2005) evaluated the National Fund for Compensation and Social Development (FONCODES) that finances drinking water, sewerage, latrine and electrification projects aimed at improving the quality of life of the poor population. One of its results is that electrification projects increased the value of homes and improved the well-being of families. Likewise, Pastor (2011) points out that there is progress in the management of sanitation in urban areas, where more than $60 \%$ of the provision of drinking water is under business control.

For 2007, the mean value of the effect of Female Head on poverty is negative and close to zero, -0.029, differing in sign from that obtained in the OLS; however, the distribution of the local effects is ambiguous, given that negative values are registered in the lower percentile and positive values in the upper percentile. This ambiguity is also present in the intercensal model; however, the mean value is positive, coinciding with that obtained in the OLS. In contrast to these results, for 2017, values are obtained with a more stable sign and in accordance with the OLS. That is, the mean value of Female Head on poverty is -0.317 , likewise, its central local coefficients fluctuate on negative values ranging from -0.460 to -0.153 .

One possible explanation for this effect is the role of mothers as direct recipients of the 
cash transfer and the main responsible for the fulfillment of the co-responsibilities of the Juntos program, a program that benefits poor households whose members include children under 19 years of age and pregnant women. This program has been the subject of several studies showing favorable results on poverty reduction and an increase in the rate of health checkups for children under 5 years of age (Perova and Vakis, 2012; Escobal and Benites, 2012). Likewise, although the program emphasizes the welfare of children to stop intergenerational poverty, there is evidence that the program also generates benefits for women by fostering greater bargaining power, which would allow them to be more involved in decisions about household resources, enabling efficient household management (Alcázar and Espinoza, 2014).

Finally, regarding Altitude, positive mean values of 0.097, 0.045 and 0.108 are obtained for 2007, 2017 and intercensal, respectively, and whose values coincide with the sign resulting from the OLS. Likewise, the distribution of the central values are stable in sign for 2007 and 2017, registering differences in the intercensal case whose values fluctuate between negative and positive values, but the latter predominating. In addition, Table 3 shows that the adjusted $R^{2}$ obtained with the GWR model for the years 2007, 2017, and intercensal increased by 19.6, 20.9, and 41.3 percentage points, compared to those obtained with OLS, which shows that the explanatory capacity of the dependent variable improves notably when applying the GWR model.

Figure 2 shows the distribution of the values of the adjusted $R^{2}$ of the GWR models at the district level. Indeed, we observed that in the case of the 2007 census, the minimum local $R^{2}$ value is $37.7 \%$ and the maximum is $99.3 \%$. These values improve in the case of the 2017 census, where the minimum value is $53.3 \%$ and the maximum is $98.1 \%$. However, in the intercensal case, the local goodness of fit is reduced to a minimum value of $13 \%$ and a maximum value of $87.7 \%$. In fact, the years 2007 and 2017 show a higher concentration of high local $R^{2}$ values, only 3 disctricts (Miraflores, Vitis and Alis in the province of Yauyos) register values below 40\%
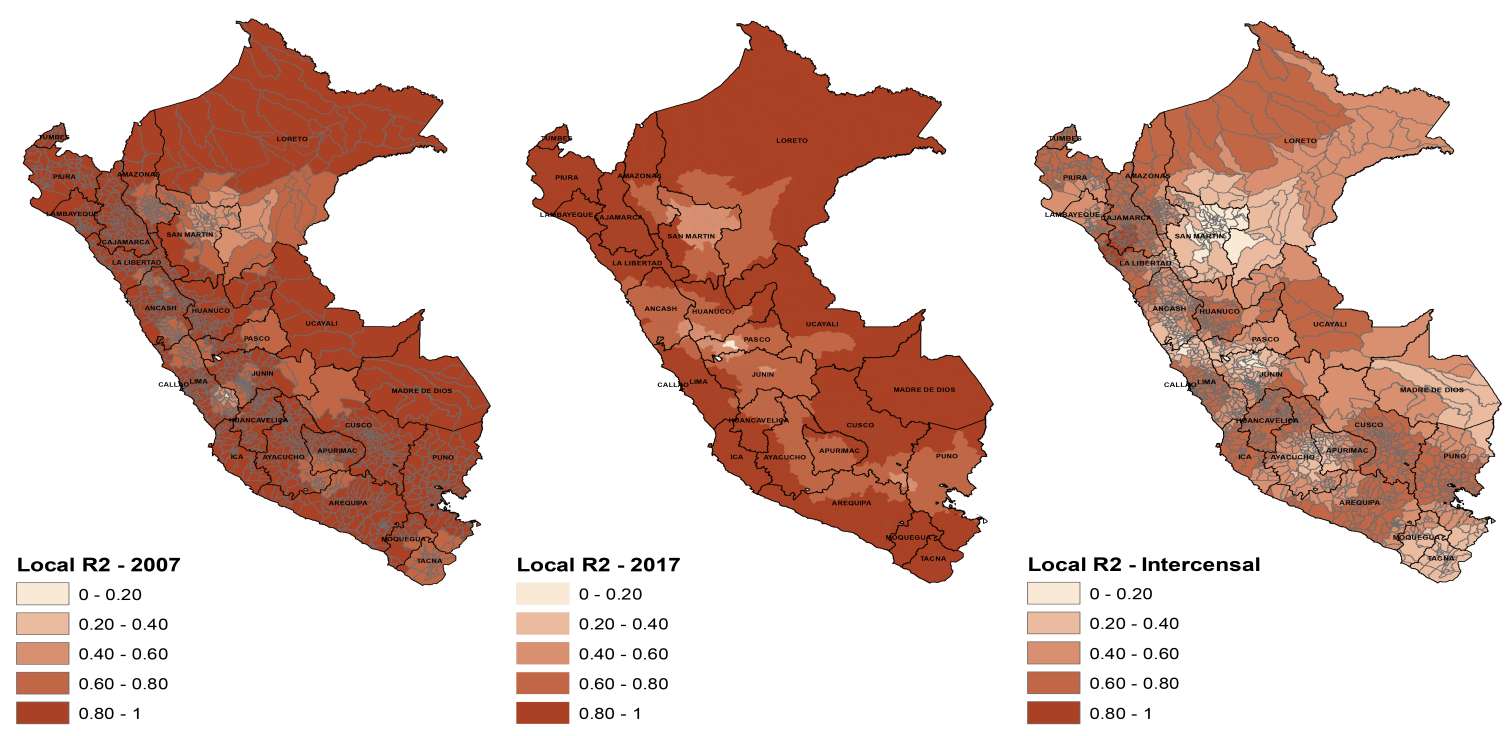

Notes: Own elaboration based on data used in the estimations.

Figure 2. Local $R^{2}$ of GWR. 
(Quintile 2). While in the intercensal, little explanatory capacity is evidenced, mainly in districts in the Northeast of the San Martín region and north of the Junín region.

The present research shows the results of the three GWR models at $1 \%$ and $5 \%$ significance for each variable analyzed. Figures 3, 4 and 5 show the maps corresponding to the 2007 and 2017 census, and intercensal to visualize the spatial behavior of the local coefficients on monetary poverty in the districts of Peru. The maps only show the signs according to the predominant number of significant coefficients for each variable in line with the literature. Additionally, summary tables for each variable according to sign and significance level are shown.

Acordding to Tables 4 and 5, in the case of Female Head for 2007, significant coefficients are almost balanced in both signs, but predominantly in negative local values. Regarding spatial distribution, it is observed that the maximum negative and significant coefficients are concentrated in the districts of Huancavelica and Junín regions, expanding towards the central zone in the districts of Pasco, Huánuco and San Martín regions. However, for 2017, the results are more stable, whose local coefficients are concentrated in negative values, and the spatial distribution of the maximum values extends to the northwest, covering districts of Piura, Cajamarca, Amazonas and La Libertad; to the northeast in the districts of Loreto; and to the center-south in districts of Junín, Huancavelica, Cusco and Ica regions. For Secondary Education, the coefficients significant at $1 \%$ and $5 \%$ are predominantly negative with a total of 696 and 825 for 2007 and 2017, respectively. For 2007, it is highlighted that $100 \%$ and $98 \%$ of districts of the Tumbes and Piura regions register a greater effect negative and significant on the poverty rate. In addition, this effect is identified in the districts located on the border of La Libertad and Áncash; Loreto and San Martín; Ucayali and Madre de Dios regions. However, for 2017, this negative and significant effect is predominantly concentrated in the districts of southeastern regions of Peru. In addition, a displacement of this effect is observed in the districts of the regions highlighted in 2007.

The significant coefficients of Unemployment are mostly positive. For 2007, the maximum significant values are registered in 46 districts located, particularly, on the border of the regions of Piura and Lambayeque; Pasco, Junín and Lima; Arequipa and Ayacucho; as well as west of San Martín and south of Arequipa. For 2017, the maximum values move to the jungle region to districts of Loreto, Ucayali and Madre de Dios; to the highlands, to districts of Puno, Junín, Pasco and Cajamarca; to the coast, to districts of La Libertad, Lima, Arequipa and Moquegua. On the other hand, for 2007 and 2017, the value of the coefficients at 1\% and 5\% significance of the Electricity variable is predominantly negative on poverty. According to the 2007 results, the coefficients are concentrated in the northwest of Peru, particularly in 100\% of districts of Tumbes and Piura regions. This effect is also concentrated in the center of the country, including districts of Pasco, Ucayali and Junín; additionally, coefficients of greater magnitude are registered in the southeast, specifically in 6 of the 11 districts of Madre de Dios, as well as in districts of southern regions such as Tacna and Moquegua. These results do not differ much from what was obtained for 2017; mainly, the changes are in Madre de Dios and Tumbes regions, where significant coefficients are no longer recorded; while an expansion of such coefficients is recorded in districts of Pasco, Ayacucho and Apurímac. Additionally, the local coefficients of the Sanitation Services variable are predominantly negative; this is evidenced by 795 and 1,293 significant coefficients

\section{; PUCP}




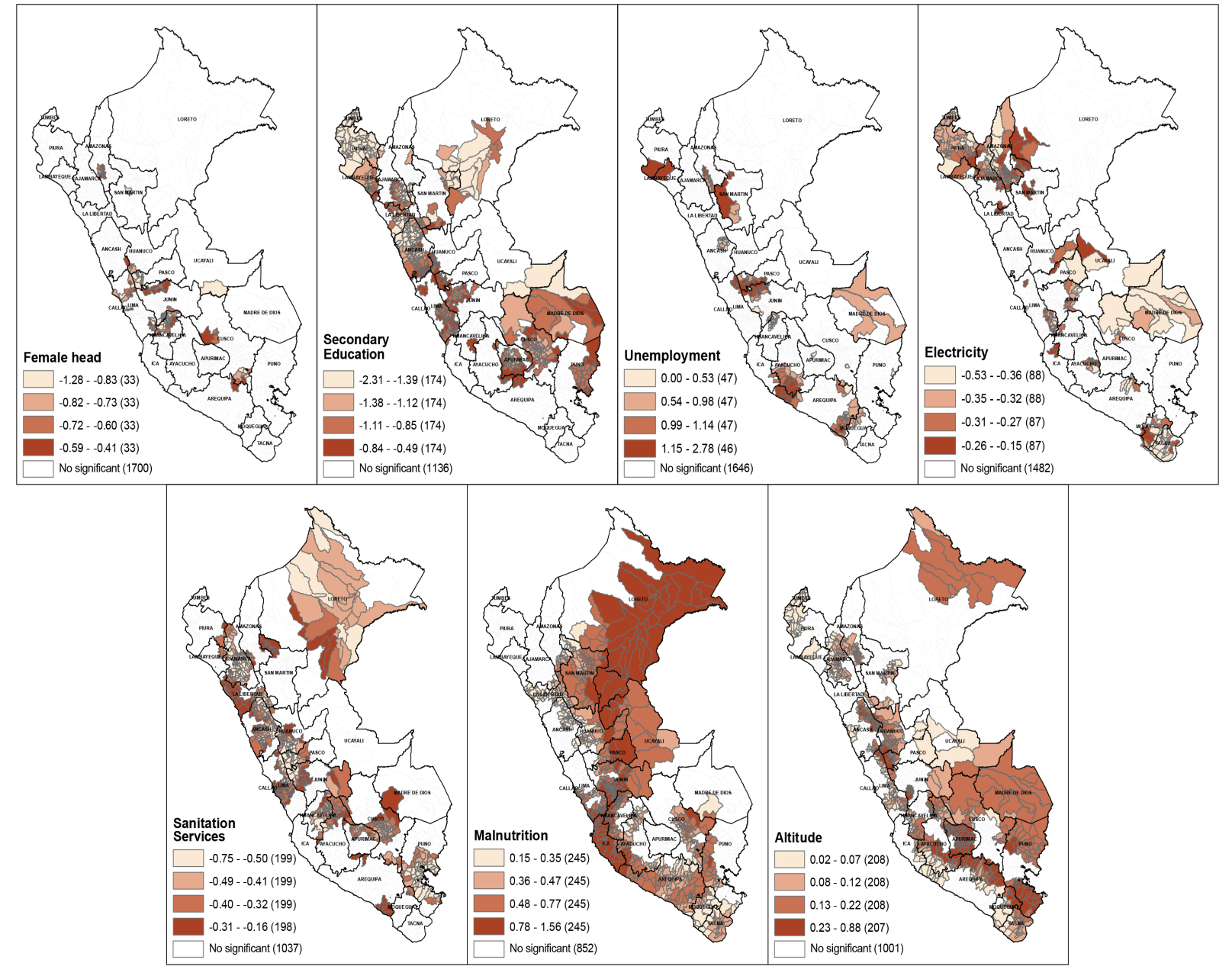

Notes: Own elaboration based on data used in the estimations. 


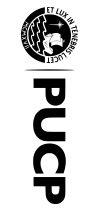
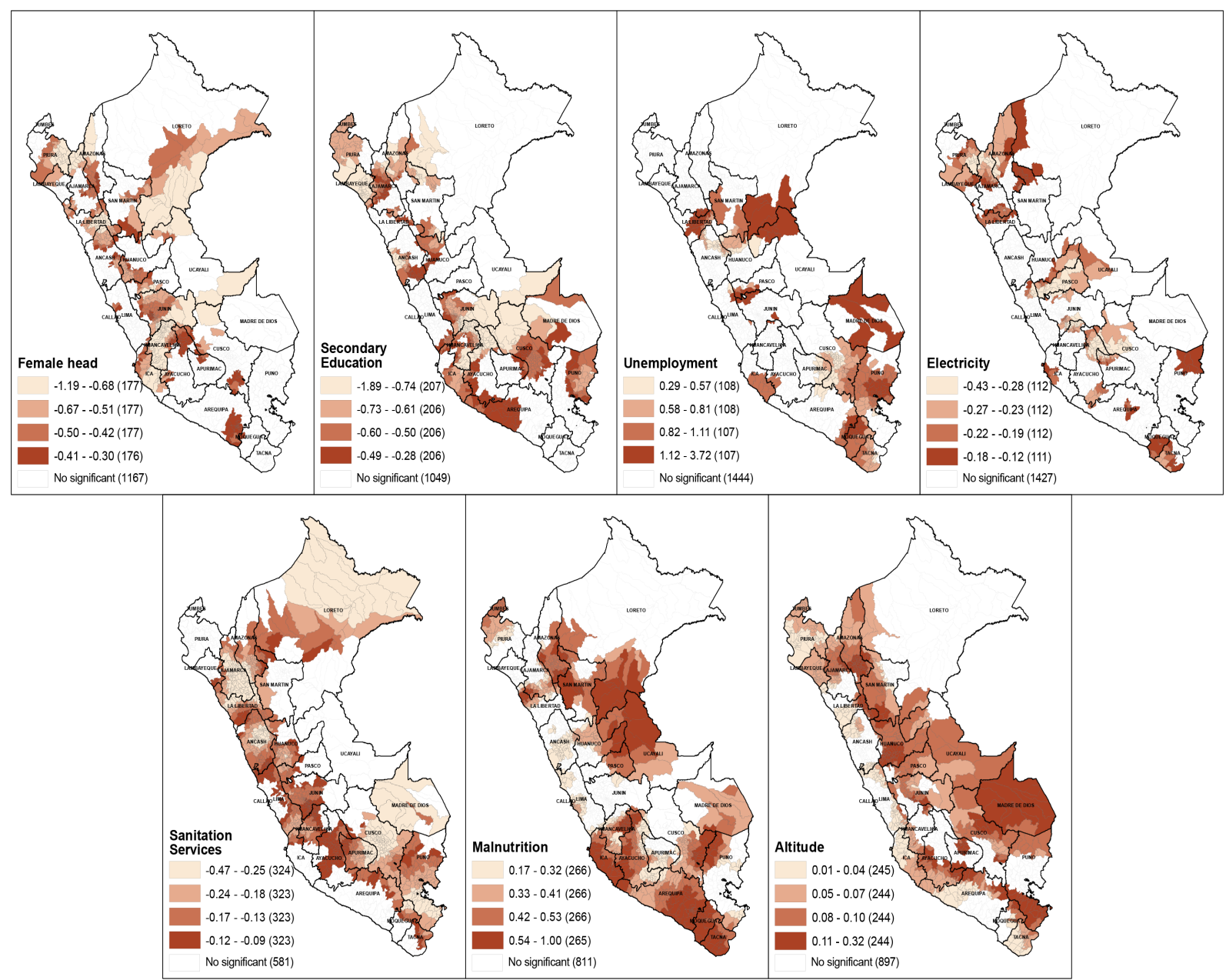

Notes: Own elaboration based on INEI.

Figure 4. Maps of significant coefficients GWR - 2017. 


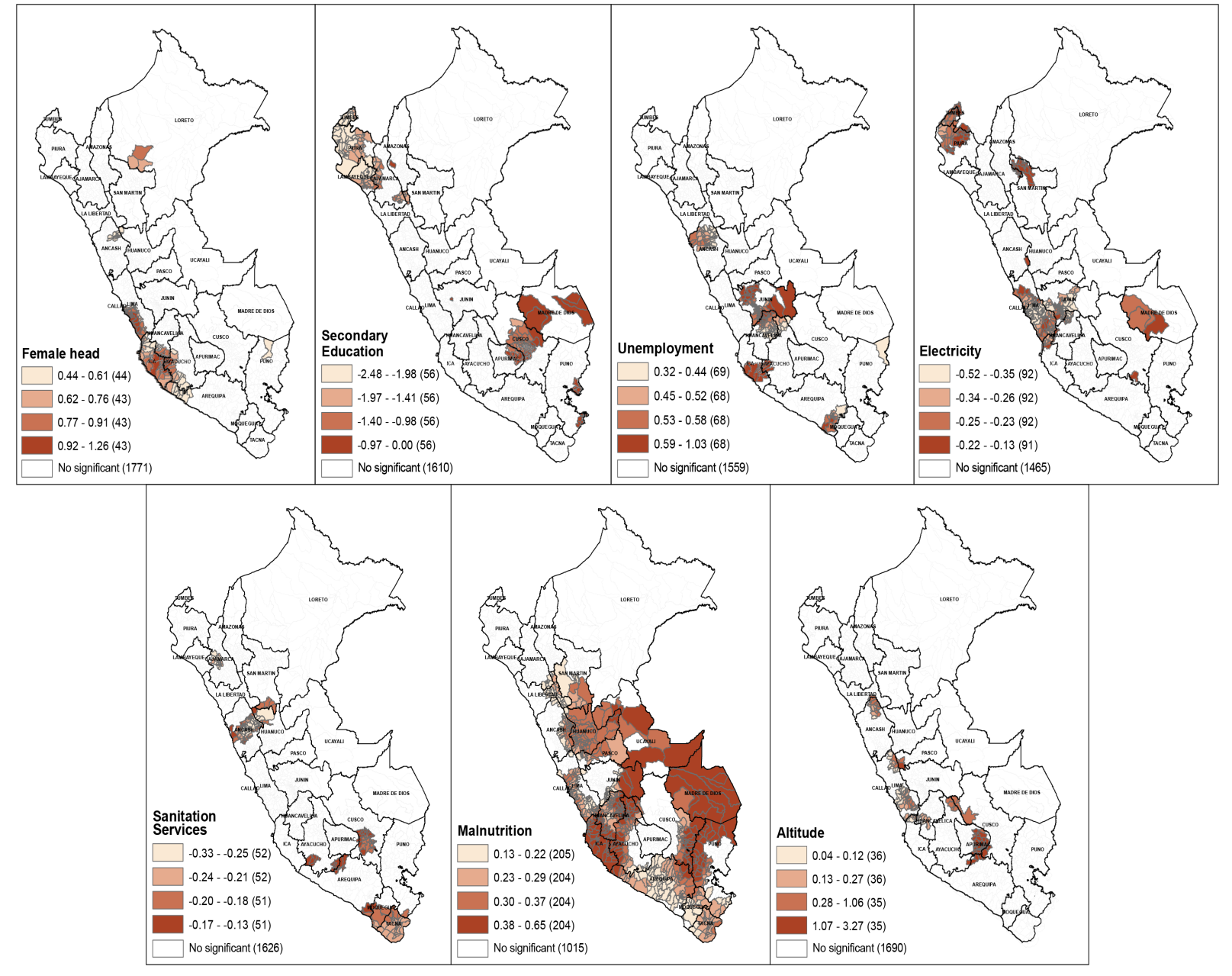

Notes: Own elaboration based on INEI.

$\frac{1}{7}$

Figure 5. Maps of significant coefficients GWR - Intercensal. 
for 2007 and 2017, respectively. For 2007, the spatial distribution of the significant coefficients is concentrated in districts in the Loreto region; then this effect shifts northwestward toward districts in Cajamarca. From there, it is concentrated in districts of the coastal regions (La Libertad, Áncash and Lima) and also includes districts of the central regions (Huánuco, Pasco, Junín) and districts of the southern highland regions (Huancavelica, Ayacucho, Apurímac, Cusco and Puno); particularly in the Puno region, $70 \%$ of its districts register negative and significant coefficients of sanitation services on poverty. For 2017, the distribution of the significant coefficients obtained in 2007 is reinforced and expanded, for example, it includes districts of Madre de Dios that register significant coefficients of greater magnitude on poverty.

Table 4

Summary of the significant coefficients of the GWR - Census 2007.

\begin{tabular}{|c|c|c|c|c|c|c|c|c|}
\hline \multirow{2}{*}{$\begin{array}{l}\text { Female Head } \\
\text { Significance }\end{array}$} & \multicolumn{4}{|c|}{ Positive } & \multicolumn{4}{|c|}{ Negative } \\
\hline & Mean & Min & Max & Obs & Mean & Min & $\operatorname{Max}$ & Obs \\
\hline $1 \%$ & 0.924 & 0.656 & 1.182 & 101 & -0.825 & -1.279 & -0.530 & 69 \\
\hline $5 \%$ & 0.627 & 0.513 & 0.779 & 28 & -0.615 & -0.994 & -0.409 & 63 \\
\hline Total & 0.327 & 0.001 & 1.182 & 774 & -0.289 & -1.279 & -0.001 & 1058 \\
\hline Secondary Education & \multicolumn{4}{|c|}{ Positive } & \multicolumn{4}{|c|}{ Negative } \\
\hline Significance & Mean & Min & $\operatorname{Max}$ & Obs & Mean & Min & $\operatorname{Max}$ & Obs \\
\hline $1 \%$ & 1.061 & 0.727 & 1.427 & 17 & -1.340 & -2.305 & -0.560 & 492 \\
\hline $5 \%$ & 0.699 & 0.478 & 0.899 & 14 & -0.806 & -1.513 & -0.488 & 204 \\
\hline Total & 0.267 & 0.001 & 1.427 & 268 & -0.736 & -2.305 & 0 & 1564 \\
\hline Unemployment & \multicolumn{4}{|c|}{ Positive } & \multicolumn{4}{|c|}{ Negative } \\
\hline Significance & Mean & Min & $\operatorname{Max}$ & Obs & Mean & Min & $\operatorname{Max}$ & Obs \\
\hline $1 \%$ & 1.153 & 0.520 & 2.782 & 82 & -2.605 & -3.944 & -1.646 & 8 \\
\hline $5 \%$ & 0.734 & 0.297 & 1.845 & 104 & -1.665 & -2.439 & -0.786 & 16 \\
\hline Total & 0.368 & 0 & 2.782 & 1179 & -0.391 & -3.944 & -0.001 & 653 \\
\hline Electricity & \multicolumn{4}{|c|}{ Positive } & \multicolumn{4}{|c|}{ Negative } \\
\hline Significance & Mean & Min & $\operatorname{Max}$ & Obs & Mean & Min & Max & Obs \\
\hline $1 \%$ & 0.353 & 0.262 & 0.564 & 19 & -0.346 & -0.530 & -0.197 & 227 \\
\hline $5 \%$ & 0.250 & 0.218 & 0.300 & 22 & -0.272 & -0.455 & -0.154 & 123 \\
\hline Total & 0.099 & 0.001 & 0.564 & 559 & -0.164 & -0.530 & 0 & 1273 \\
\hline Sanitation services & \multicolumn{4}{|c|}{ Positive } & \multicolumn{4}{|c|}{ Negative } \\
\hline Significance & Mean & Min & Max & Obs & Mean & Min & Max & Obs \\
\hline $1 \%$ & 0.426 & 0.373 & 0.491 & 4 & -0.462 & -0.752 & -0.228 & 548 \\
\hline $5 \%$ & 0.350 & 0.335 & 0.365 & 2 & -0.322 & -0.569 & -0.157 & 247 \\
\hline Total & 0.095 & 0 & 0.491 & 237 & -0.278 & -0.752 & 0 & 1595 \\
\hline Malnutrition & \multicolumn{4}{|c|}{ Positive } & \multicolumn{4}{|c|}{ Negative } \\
\hline Significance & Mean & Min & Max & Obs & Mean & Min & Max & Obs \\
\hline $1 \%$ & 0.657 & 0.199 & 1.557 & 753 & -0.421 & -0.426 & -0.417 & 2 \\
\hline $5 \%$ & 0.344 & 0.145 & 1.349 & 227 & -0.362 & -0.483 & -0.217 & 31 \\
\hline Total & 0.425 & 0.001 & 1.557 & 1568 & -0.126 & -0.483 & 0 & 264 \\
\hline Ln(Altitude) & \multicolumn{4}{|c|}{ Positive } & \multicolumn{4}{|c|}{ Negative } \\
\hline Significance & Mean & Min & $\operatorname{Max}$ & Obs & Mean & Min & $\operatorname{Max}$ & Obs \\
\hline $1 \%$ & 0.194 & 0.024 & 0.880 & 601 & -0.112 & -0.426 & -0.055 & 24 \\
\hline $5 \%$ & 0.145 & 0.021 & 0.731 & 230 & -0.204 & -0.641 & -0.041 & 7 \\
\hline Total & 0.124 & 0 & 0.880 & 1590 & -0.085 & -0.642 & 0 & 242 \\
\hline
\end{tabular}

Note: Own elaboration based on data used in the estimations. 
Table 5

Summary of the significant coefficients of the GWR - Census 2017.

\begin{tabular}{|c|c|c|c|c|c|c|c|c|}
\hline \multirow{2}{*}{$\begin{array}{c}\text { Female Head } \\
\text { Significance }\end{array}$} & \multicolumn{4}{|c|}{ Positive } & \multicolumn{4}{|c|}{ Negative } \\
\hline & Mean & Min & $\operatorname{Max}$ & Obs & Mean & Min & Max & Obs \\
\hline $1 \%$ & 0.466 & 0.466 & 0.466 & 1 & -0.665 & -1.189 & -0.393 & 401 \\
\hline $5 \%$ & 0.406 & 0.325 & 0.509 & 4 & -0.430 & -0.757 & -0.297 & 306 \\
\hline Total & 0.129 & 0.001 & 0.509 & 199 & -0.371 & -1.189 & 0 & 1675 \\
\hline Secondary Education & \multicolumn{4}{|c|}{ Positive } & \multicolumn{4}{|c|}{ Negative } \\
\hline Significance & Mean & Min & Max & Obs & Mean & Min & $\operatorname{Max}$ & Obs \\
\hline $1 \%$ & 0.527 & 0.320 & 0.632 & 60 & -0.734 & -1.885 & -0.381 & 464 \\
\hline $5 \%$ & 0.324 & 0.261 & 0.509 & 17 & -0.527 & -1.843 & -0.284 & 361 \\
\hline Total & 0.215 & 0.001 & 0.632 & 294 & -0.466 & -1.885 & 0 & 1580 \\
\hline Unemployment & \multicolumn{4}{|c|}{ Positive } & \multicolumn{4}{|c|}{ Negative } \\
\hline Significance & Mean & Min & Max & Obs & Mean & Min & $\operatorname{Max}$ & Obs \\
\hline $1 \%$ & 1.145 & 0.418 & 3.719 & 249 & -2.028 & -2.213 & -1.887 & 3 \\
\hline $5 \%$ & 0.699 & 0.291 & 1.830 & 181 & -1.718 & -2.151 & -1.163 & 17 \\
\hline Total & 0.514 & 0.001 & 3.719 & 1462 & -0.378 & -2.213 & -0.001 & 412 \\
\hline Electricity & \multicolumn{4}{|c|}{ Positive } & \multicolumn{4}{|c|}{ Negative } \\
\hline Significance & Mean & Min & Max & Obs & Mean & Min & Max & Obs \\
\hline $1 \%$ & 0.248 & 0.165 & 0.338 & 11 & -0.273 & -0.433 & -0.168 & 207 \\
\hline $5 \%$ & 0.199 & 0.138 & 0.243 & 15 & -0.200 & -0.316 & -0.118 & 240 \\
\hline Total & 0.063 & 0 & 0.338 & 381 & -0.132 & -0.433 & -0.001 & 1493 \\
\hline Sanitation services & \multicolumn{4}{|c|}{ Positive } & \multicolumn{4}{|c|}{ Negative } \\
\hline Significance & Mean & Min & Max & Obs & Mean & Min & $\operatorname{Max}$ & Obs \\
\hline $1 \%$ & - & - & - & - & -0.219 & -0.470 & -0.107 & 1,035 \\
\hline $5 \%$ & - & - & - & - & -0.122 & -0.297 & -0.088 & 258 \\
\hline Total & 0.024 & 0.001 & 0.087 & 47 & -0.160 & -0.470 & -0.001 & 1,827 \\
\hline Malnutrition & \multicolumn{4}{|c|}{ Positive } & \multicolumn{4}{|c|}{ Negative } \\
\hline Significance & Mean & Min & Max & Obs & Mean & Min & $\operatorname{Max}$ & Obs \\
\hline $1 \%$ & 0.481 & 0.229 & 0.995 & 791 & - & - & - & - \\
\hline $5 \%$ & 0.301 & 0.167 & 0.475 & 272 & -0.147 & -0.166 & -0.130 & 6 \\
\hline Total & 0.330 & 0 & 0.995 & 1,701 & -0.051 & -0.192 & 0 & 173 \\
\hline Ln(Altitude) & \multicolumn{4}{|c|}{ Positive } & \multicolumn{4}{|c|}{ Negative } \\
\hline Significance & Mean & Min & Max & Obs & Mean & Min & Max & Obs \\
\hline $1 \%$ & 0.076 & 0.017 & 0.317 & 766 & -0.072 & -0.111 & -0.049 & 18 \\
\hline $5 \%$ & 0.069 & 0.013 & 0.262 & 211 & -0.167 & -0.448 & -0.033 & 20 \\
\hline Total & 0.063 & 0 & 0.317 & 1582 & -0.054 & -0.448 & 0 & 292 \\
\hline
\end{tabular}

Note: Own elaboration based on data used in the estimations.

As can be seen in Tables 4 and 5, a total of 980 and 1,063 local coefficients of the variable Malnutrition are positive and significant for 2007 and 2017, respectively. In 2007, the significant values of quintile 5 are concentrated mainly in districts of the Loreto region; then they are located in San Martín and Ucayali regions, as well as in the central zone of Peru in the districts of Huánuco, Pasco, and Junín regions. Later, maximum positive values are registered in the southwest, encompassing the districts of Huancavelica, Lima, and, particularly, Ica region, where $95 \%$ of their districts register high values. In 2017, the magnitude of the coefficient increased in the districts of Tacna, Moquegua, and Arequipa regions. Besides new districts with significant coefficients in Madre de Dios, Tumbes, and Piura regions were registered; however, 
Table 6

Summary of the significant coefficients of the GWR - Intercensal.

\begin{tabular}{|c|c|c|c|c|c|c|c|c|}
\hline \multirow{2}{*}{$\begin{array}{l}\text { Female Head } \\
\text { Significance }\end{array}$} & \multicolumn{4}{|c|}{ Positive } & \multicolumn{4}{|c|}{ Negative } \\
\hline & Mean & Min & Max & Obs & Mean & Min & $\operatorname{Max}$ & Obs \\
\hline $1 \%$ & 0.890 & 0.635 & 1.258 & 112 & -0.738 & -0.880 & -0.662 & 4 \\
\hline $5 \%$ & 0.569 & 0.438 & 0.889 & 61 & -0.624 & -0.924 & -0.477 & 55 \\
\hline Total & 0.314 & 0.001 & 1.258 & 1079 & -0.212 & -0.924 & -0.001 & 753 \\
\hline Secondary Education & \multicolumn{4}{|c|}{ Positive } & \multicolumn{4}{|c|}{ Negative } \\
\hline Significance & Mean & Min & Max & Obs & Mean & Min & $\operatorname{Max}$ & Obs \\
\hline $1 \%$ & 1.066 & 0.695 & 1.349 & 52 & -1.662 & -2.477 & -0.858 & 133 \\
\hline $5 \%$ & 0.770 & 0.496 & 1.388 & 46 & -1.138 & -2.113 & -0.539 & 89 \\
\hline Total & 0.343 & 0 & 1.388 & 983 & -0.650 & -2.477 & 0 & 849 \\
\hline Unemployment & \multicolumn{4}{|c|}{ Positive } & \multicolumn{4}{|c|}{ Negative } \\
\hline Significance & Mean & Min & Max & Obs & Mean & Min & $\operatorname{Max}$ & Obs \\
\hline $1 \%$ & 0.614 & 0.464 & 1.029 & 71 & -1.010 & -1.426 & -0.484 & 24 \\
\hline $5 \%$ & 0.495 & 0.319 & 0.906 & 202 & -1.136 & -1.431 & -0.474 & 51 \\
\hline Total & 0.295 & 0 & 1.029 & 1130 & -0.356 & -1.431 & -0.001 & 702 \\
\hline Electricity & \multicolumn{4}{|c|}{ Positive } & \multicolumn{4}{|c|}{ Negative } \\
\hline Significance & Mean & Min & Max & Obs & Mean & Min & $\operatorname{Max}$ & Obs \\
\hline $1 \%$ & 0.229 & 0.213 & 0.242 & 6 & -0.324 & -0.521 & -0.195 & 227 \\
\hline $5 \%$ & 0.171 & 0.133 & 0.235 & 52 & -0.211 & -0.296 & -0.127 & 140 \\
\hline Total & 0.082 & 0 & 0.242 & 490 & -0.134 & -0.521 & -0.001 & 1342 \\
\hline Sanitation services & \multicolumn{4}{|c|}{ Positive } & \multicolumn{4}{|c|}{ Negative } \\
\hline Significance & Mean & Min & Max & Obs & Mean & Min & Max & Obs \\
\hline $1 \%$ & 0.236 & 0.157 & 0.310 & 68 & -0.253 & -0.311 & -0.188 & 82 \\
\hline $5 \%$ & 0.188 & 0.123 & 0.269 & 61 & -0.194 & -0.327 & -0.132 & 124 \\
\hline Total & 0.088 & 0 & 0.310 & 842 & -0.101 & -0.327 & 0 & 990 \\
\hline Malnutrition & \multicolumn{4}{|c|}{ Positive } & \multicolumn{4}{|c|}{ Negative } \\
\hline Significance & Mean & Min & Max & Obs & Mean & Min & $\operatorname{Max}$ & Obs \\
\hline $1 \%$ & 0.345 & 0.175 & 0.651 & 603 & -0.342 & -0.496 & -0.218 & 97 \\
\hline $5 \%$ & 0.213 & 0.134 & 0.453 & 214 & -0.207 & -0.436 & -0.142 & 87 \\
\hline Total & 0.235 & 0.001 & 0.651 & 1311 & -0.163 & -0.496 & 0 & 521 \\
\hline Ln(Altitude) & \multicolumn{4}{|c|}{ Positive } & \multicolumn{4}{|c|}{ Negative } \\
\hline Significance & Mean & Min & $\operatorname{Max}$ & Obs & Mean & Min & Max & Obs \\
\hline $1 \%$ & 0.749 & 0.063 & 3.267 & 73 & - & - & - & - \\
\hline $5 \%$ & 0.555 & 0.044 & 2.141 & 69 & -0.785 & -2.115 & -0.104 & 36 \\
\hline Total & 0.279 & 0 & 3.267 & 1251 & 0.258 & -2.115 & 0 & 581 \\
\hline
\end{tabular}

Note: Own elaboration based on data used in the estimations.

the Junín and Loreto regions no longer have significant in large proportion as in 2007. Regarding the distribution of the local values of the Altitude variable, a greater number of positive and significant coefficients are observed for both years analyzed. For 2007, the high values of the significant coefficients are concentrated in the districts in the south of the country, as well as in districts in the center, which includes the regions of Huánuco, Áncash and Pasco. In the case of 2017, the number of districts with significant coefficients increased by 146 distributed, mainly, in the north (Amazonas); center (San Martín, Huánuco, Pasco, Junín and Ucayali); and southeast (Cusco, Madre de Dios and Puno). 
Table 6 summarizes the results of the intercensal model. In the case of Female Head, there is a higher concentration of positive and significant coefficients; these significant coefficients are located, specifically, in the districts of Lima and in the border districts between the regions of Ica, Ayacucho and Huancavelica. However, this result is contrary to what was obtained in 2017, whose result indicates that the border districts of those regions register the maximum negative and significant values of Female Head on poverty. Regarding the other variables, a similar behavior to what was obtained in 2007 and 2017 is observed in the signs of the coefficients of the intercensal model; but there are differences in the spatial distribution. However, it is important to note that the estimates obtained from the intercensal model do not conform to what was expected in the face of both anomalous results in the spatial distribution and low explanatory capacity, as shown above with the adjusted $R^{2}$.

\section{Conclusions}

In Peru, the literature has mainly focused on poverty analysis at an aggregate level. Therefore, the main contribution of this research is to conduct the analysis at the local level, that is, to analyze the factors that explain the spatial heterogeneity of monetary poverty in each district of the Peruvian territory.

The methodology used in this study is based on the Geographically Weighted Regression model, which allows us to capture the non-stationary spatial component of poverty in the districts. Unlike a global regression model, this approach makes it possible to obtain estimators for each territorial administration and to formulate policies that help identify the districts whose factors associated with poverty are lagging behind. Likewise, the application of the GWR model shows a notable improvement in the explanatory capacity with respect to that obtained with the OLS model. Likewise, it should be noted that a Monte Carlo simulation was run, from which it was determined that all the coefficients are locally variable variables affected by the local context, which allows us to register a heterogeneous impact on poverty.

The results of this research allow us to identify districts with significant local coefficients. In general, the estimates show that the increase in secondary education, electricity, sanitation services and female headship have an effect on poverty reduction at the local level. For 2007, these significant effects are mainly concentrated in the districts of the province of Daniel Alcides Carrión and Pasco in Pasco region; in Huarochirí, Oyón and Yauyos in Lima region; and in Celendín, Chota and San Ignacio in Cajamarca region. For 2017, the results show a shift towards districts in the province of Chupaca, Concepción, Huancayo in Junín region; in Huancavelica and Tayacaja in Huancavelica region; and in Jaen, San Marcos in Cajamarca region.

On the contrary, an increase in unemployment, malnutrition and altitude do not contribute to poverty reduction. For 2007, these significant effects predominate in the districts of the province of Mariscal Luzuriaga, Carlos Fermin Fitzcarrald in Áncash region; in Caravelí, Caylloma in Arequipa region; and in Lucanas and Parinacochas in Ayacucho region. For 2017, this effect is reinforced in the south in districts of the provinces of Canchis, Quispicanchi, Paucartambo, Canas and Calca in Cusco region; in Candarave, Jorge Basadre, Tacna and Tarata in Tacna region; and in Huaylas, Huari and Antonio Raymondi in Áncash region. 
From the results, the existence of heterogeneous spatial dynamics on poverty at the district level is clearly evidenced. This allows us to visualize in which districts, for example, educational policies are succeeding in combating poverty, practices that could be scaled up to the national level. However, we can also visualize those districts where the relationship is not favorable in poverty reduction; therefore, the focus of territorial policy should concentrate on these territories. The possibility of identifying the least favored districts rigorously and accurately promotes a new public management model that allows the design of policies based on the particular conditions of each territory, thus achieving more efficiency and equity in regional development.

Based on the above-mentioned empirical results, the highlighted policy implications are as follows: (1) establish strategies to attract public and private investments in intermediate cities that allow for a fluid economic dynamic; (2) rural poverty should be further explored at the district level because it is where the highest poverty rates have been evidenced; therefore, one of the policy proposals is the construction of functional territories, with the purpose of articulating the territories as an agricultural labor market or other sectors that contribute to community development develops; (3) promote the development of productive infrastructure for the creation of appropriate conditions for the development of the endogenous potential of the district space; (4) allocate budget to subnational governments with higher poverty rates that have strategies focused on implementing, for example, educational policies or access to basic services such as electricity, sanitation and water to the poorest households, conditioned to efficient budget execution.

Finally, we would like to acknowledge the main limitations in this study. First, there are different methods to measure poverty. Although at present the multidimensional approach predominates, the official and accepted measure for Peru is monetary poverty. Second, we have observed an increase from 1,832 to 1,874 districts between the period 2007 and 2017. In this regard, the intercensal model only considers districts found in both censuses, which means that 42 districts created around 2017 are not considered. Third, a convergence problem has been observed with the semiparametric estimation approach (non-invertible Hessian) as more variables were introduced to the GWR model. For that reason, we decide to limit the number of variables, based on a multicollinearity analysis (VIF) test to exclude highly correlated variables. Finally, it is worth mentioning that this paper focuses on the role of observed spatial heterogeneity and that causality remains a topic for future research. 


\section{References}

Alcázar, L., and Espinoza, K. (2014). Impactos del programa Juntos sobre el empoderamiento de la mujer. Serie: Avances de Investigación 19. Lima: Grupo de Análisis para el Desarrollo (GRADE).

Alcázar, L., Ocampo, D., Huamán-Espino, L., and Pablo Aparco, J. (2013). Impacto económico de la desnutrición crónica, aguda y global en el Perú. Revista Peruana de Medicina Experimental y Salud Pública 30(4), 569-574.

Aldana, U., Clausen, J., Cozzubo, A., Trivelli, C., Urrutia, C., and Yancari, J. (2019). Desigualdad y pobreza en un contexto de crecimiento económico. Lima: Instituto de Estudios Peruanos.

Aparicio, C., Jaramillo, M., and San Román, C. (2011). Desarrollo de la infraestructura y reducción de la pobreza: el caso peruano. CIES, Universidad del Pacífico.

Becker, W. C. (1964). Consequences of different kinds of parental discipline. In M. L. Hoffman and L. W. Hoffman (Eds.), Review of Child Development Research (pp. 169-208). New York: Russell Sage Foundation.

Benavides, M. (2004). Educación y estructura social en el Perú. Un estudio acerca del acceso a la educación superior y la movilidad intergeneracional en una muestra de trabajadores urbanos. In P. Arregui, M. Benavides, S. Cueto, B. Hunt, J. Saavedra, and W. Secada (Eds.), ¿Es posible mejorar la educación peruana?: Evidencias y posibilidades (pp. 125146). Lima: Grupo de Análisis para el Desarrollo (GRADE).

Bird, K., McKay, A., and Shinyekwa, I. (2011). Isolation and poverty: the relationship between spatially differentiated access to goods and services and poverty. Working Paper 322. Overseas Development Institute (ODI).

Blumberg, R. L. (1995). Introduction: Engendering Wealth and Well-Being in an Era of Economic Transformation. In R. L. Blumberg, C. Rakowski, I. Tinker, and M. Monteón (Eds.), EnGENDERring Wealth and Well-being: Empowerment for Global Change (pp. 1-14). Boulder: Westview.

Bowman, A. W., and Azzalini, A. (1997). Applied Smoothing Techniques for Data Analysis: The Kernel approach with S-Plus illustrations, vol. 18. Oxford: Clarendon Press.

Brunsdon, C., Fotheringham, A. S., and Charlton, M. E. (1996). Geographically Weighted Regression: A Method for Exploring Spatial Nonstationarity. Geographical Analysis 28 (4), 281-298.

CAF (2014). Vulnerability Index to climate change in the Latin American and Caribbean Region. Caracas: CAF.

Chant, S. (2003). Nuevas contribuciones al análisis de la pobreza: desafíos metodológicos y conceptuales para entender la pobreza desde una perspectiva de género. Serie: Mujer y Desarrollo No. 47. Santiago de Chile: CEPAL.

Clausen, J., and Flor, J. L. (2014). Sobre la naturaleza multidimensional de la pobreza humana: propuesta conceptual e implementación empírica para el caso peruano. Documento de Trabajo No. 387. Departamento de Economía, Pontificia Universidad Católica del Perú. 
Cleveland, W. S. (1979). Robust Locally Weighted Regression and Smoothing Scatterplots. Journal of the American Statistical Association 74 (368), 829-836.

Cord, L., Genoni, M., and Rodríguez-Castelán, C. (2015). Shared Prosperity and Poverty Eradication in Latin America and the Caribbean. Washington, DC: The World Bank.

Cortés, F. (1997). Determinantes de la pobreza de los hogares. México, 1992. Revista Mexicana de Sociología 59 (2), 131-160.

Escobal, J., and Benites, S. (2012). Algunos impactos del programa JUNTOS en el bienestar de los niños: Evidencia basada en el estudio Niños del Milenio. Boletín de políticas públicas sobre infancia, 5. Lima: Niños del Milenio.

Escobal, J., and Ponce, C. (2016). Dinámicas provinciales de pobreza en el Perú (1993-2007). In F. Modrego Benito and J. A. Berdegué (Eds.), Los dilemas territoriales del desarrollo en América Latina (pp. 187-210). Bogotá: Ediciones Uniandes.

Escobal, J., Saavedra, J., and Torero, M. (1999). Los activos de los pobres en el Perú. El Trimestre Económico 66 (263(3)), 619-659.

Farber, S., and Páez, A. (2007). A systematic investigation of cross-validation in GWR model estimation: empirical analysis and Monte Carlo simulations. Journal of Geographical Systems 9(4), 371-396.

Fotheringham, A. S., Brunsdon, C., and Charlton, M. (2003). Geographically Weighted Regression: The Analysis of Spatially Varying Relationships. John Wiley \& Sons.

Fotheringham, A. S., Charlton, M. E., and Brunsdon, C. (2001). Spatial Variations in School Performance: A Local Analysis using Geographically Weighted Regression. Geographical and Environmental Modelling 5(1), 43-66.

Franco, A. P., and Nopo, H. (2018). Ser joven en el Perú: Educación y Trabajo. Serie: Avances de Investigación 37. Lima: Grupo de Análisis para el Desarrollo (GRADE).

Fukusaki, G. Y., and Pérez, P. (2005). Evaluación de impacto de proyectos de desarrollo en el Perú. Serie: Apuntes de Estudio No. 61. Lima: Universidad del Pacifico.

Herrera, J., and Cozzubo, A. (2016). La Vulnerabilidad de los hogares a la pobreza en el Perú, 2004-2014. Document de travail 2016/08, DIAL. Développement, Institutions et Mondialisation. Université Paris-Dauphine.

Jalan, J., and Ravallion, M. (2002). Geographic Poverty Traps? A Micro Model of Consumption Growth in Rural China. Journal of Applied Econometrics 17(4), 329-346.

Kabeer, N. (2003). Gender Mainstreaming in Poverty Eradication and the Millennium Development Goals: A handbook for policy-makers and other stakeholders. London: Commonwealth Secretariat.

Kraay, A., and McKenzie, D. (2014). Do Poverty Traps Exist? Assessing the Evidence. Journal of Economic Perspectives 28(3), 127-148.

Leung, Y., Mei, C.-L., and Zhang, W.-X. (2000). Statistical tests for spatial nonstationarity based on the geographically weighted regression model. Environment and Planning A 32(1), 9-32.

Li, T., Cao, X., Qiu, M., and Li, Y. (2020). Exploring the Spatial Determinants of Rural Poverty in the Interprovincial Border Areas of the Loess Plateau in China: A Village-Level Anal- 
ysis using Geographically Weighted Regression. ISPRS International Journal of GeoInformation $9(6), 345$.

Li, Z., and Fotheringham, A. S. (2020). Computational improvements to multi-scale geographically weighted regression. International Journal of Geographical Information Science 34 (7), 1378-1397.

Mahoozi, H. (2015). Gender and spatial disparity of multidimensional poverty in Iran. OPHI Working Paper No. 95. Queen Elizabeth House, University of Oxford.

Mei, C.-L., He, S.-Y., and Fang, K.-T. (2004). A Note on the Mixed Geographically Weighted Regression Model. Journal of Regional Science 44 (1), 143-157.

Minam (2014). El Perú y el Cambio Climático: Tercera Comunicación Nacional del Perú a la Convención Marco de las Naciones Unidas sobre Cambio Climático. Ministerio del Ambiente. Lima: Perú.

Moghadam, V. (1997). The Feminisation of Poverty: Notes on a Concept and Trend. Occasional Paper No. 2. Women's Studies Program, Illinois State University.

Moran, P. A. (1950). Notes on Continuous Stochastic Phenomena. Biometrika 37(1/2), 17-23.

Olivia, S., Gibson, J., Rozelle, S., Huang, J., and Deng, X. (2011). Mapping poverty in rural China: how much does the environment matter? Environment and Development Economics 16 (2), 129-153.

Oppong, C. (1997). African family systems and socio-economic crisis. In A. Adepoju (Ed.), Family, Population and Development in Africa (pp. 158-182). London and New Jersey: Zed Books.

Ordaz, J. L. (2009). México: Impacto de la educación en la pobreza rural. Serie: Estudios y Perspectivas No. 105. Ciudad de México: CEPAL.

Paes de Barros, R., De Carvalho, M., and Franco, S. (2006). Pobreza multidimensional no Brasil. Texto para discussão No. 1227. Brazil: Instituto de Pesquisa Econômica Aplicada (IPEA).

Páez, A., Uchida, T., and Miyamoto, K. (2002). A general framework for estimation and inference of geographically weighted regression models: 2. Spatial association and model specification tests. Environment and Planning A 34 (5), 883-904.

Pagan, A., and Ullah, A. (1999). Nonparametric Econometrics. Cambridge: Cambridge University Press.

Pastor, C. (2011). Infraestructura y pobreza en el Perú. In O. Jacob (Ed.), Inversion en infraestructura pública y reducción de la pobreza en América Latina (pp. 116-124). Rio de Janeiro: Konrad Adenauer Stiftung.

Perova, E., and Vakis, R. (2012). 5 years in Juntos: New Evidence on the Program's Short and Long-Term Impacts. Economía 35 (69), 53-82.

Qu, W., Tu, Q., Niu, S., and Hu, M. (2012). Testing the effect of Natural geographical environment on the poor: the empirical analysis of the impact of natural geographical conditions on rural poverty. Chinese Rural Economy 2, 21-34.

Reátegui, L., Cuenca, R., Ríos, C. d. 1., Ortiz, G., and Carrillo, S. (2017). La calidad y equidad de la educación secundaria en el Perú. Serie: Educación 16. Lima: Instituto de Estudios Peruanos. 
Reinikka, R., and Svensson, J. (1999). How Inadequate Provision of Public Infrastructure and Services Affects Private Investment. Policy Research Working Paper Series 2262. The World Bank.

Sanchez, A., Melendez, G., and Behrman, J. (2016). The impact of the Juntos Conditional Cash Transfer Programme in Peru on Nutritional and Cognitive Outcomes: Does the Age of Exposure Matter? Working Paper 153. Young Lives.

Saunders, P. (2002). The Ends and Means of Welfare: Coping with Economic and Social Change in Australia. Cambridge: Cambridge University Press.

Segura, J. L., Montes, C., Hilarío, M., Asenjo, P., and Baltazar, G. (2002). Pobreza y Desnutrición Infantil. Lima: PRISMA ONGD.

Van Kerm, P. (2003). Adaptive kernel density estimation. The Stata Journal 3(2), 148-156.

Verdera, F. (2007). La pobreza en el Perú: un análisis de sus causas y de las políticas para enfrentarla. Serie: Análisis Económico 24. Lima: Instituto de Estudios Peruanos.

Wheeler, D. C., and Páez, A. (2010). Geographically Weighted Regression. In M. M. Fischer and A. Getis (Eds.), Handbook of Applied Spatial Analysis (pp. 461-486). Berlin, Heidelberg: Springer-Verlag.

World-Bank (2006). Revalorizacion del papel fundamental de la nutrición para el desarrollo. Estrategia para una intervencion en gran escala. Panorama general. Washington, DC: The World Bank.

Xu, Z., Cai, Z., Wu, S., Huang, X., Liu, J., Sun, J., Su, S., and Weng, M. (2019). Identifying the Geographic Indicators of Poverty Using Geographically Weighted Regression: A Case Study from Qiandongnan Miao and Dong Autonomous Prefecture, Guizhou, China. Social Indicators Research 142(3), 947-970.

Yamada, G., and Montero, R. (2008). Desempleo, pobreza y estrategias de protección social: Perú 1998-2005. Documento de Discusión, DD/08/03. Lima: Centro de Investigación de la Universidad del Pacífico. 